\title{
The Moulding of the Scientist Individual in Frankenstein*
}

\author{
Shamil Taha ABDULLAH ${ }^{* *}$
}

The Moulding of the Scientist Individual in Frankenstein

Abstract

This article aims at examining the fashioning of the scientist figure in Mary Shelley's Frankenstein. The article suggests that the novel is informative about the status of science at the beginning of the nineteenth century. Shelley's pessimistic attitude towards science precludes noticing the embedded and informative particulars which, if put together, can produce a comprehensible image about the circumstances of scientific ventures in the post-Faustian era. This article shows that in Frankenstein the scientist is perplexed by the branching of the Renaissance sciences and fields and the birth of new subfields and disciplines. Frankenstein and Walton are the specialized and devoted scientists of the transitional era who are divided between the science of the Faustian paradigm and the newly emerging scientific conduct of the nineteenth century. The article argues that the tragic fate of the hero in the novel is brought about by scientific hubris

Key Words: Literary Criticism, Social Theory, Disenchantment, Renaissance, Faustian Figures.
Frankenstein Romanında Bilim Adamı Figürünün Şekillenmesi

Özet

Bu makalede, Mary "Frankenstein" romanında bilim adamı figürünün incelenmesi amaçlanmıştır. Roman 20. Yüzyıl başlarında bilimin yerini tartışmakta ve bilim konusunda son derece kapsamlı bilgiler sunmaktadır. Makalede, Shelly'nin bilime karşı karamsar bakış açısı, Faust sonrası dönemde bilimsel girişimlerin şartlarını ortaya koyan bir resim ile aydınlatıcı ayrıntıların farkına varılmasının önüne geçtiği düşünülmektedir. Romanında bilim adamı, Rönesans'ta bilimin dallara ayrılmasından ve çeşitli alt dalların ve disiplinlerin ortaya çıkmasındaki şaşkınlığını belirtmektedir. Frankenstein ve Walton, Faustian paradigmasının bilimi ve on dokuzuncu yüzylın yeni ortaya çıkmakta olan bilimsel davranışları arasında bölünmüş geçiş döneminin uzman ve özverili bilim insanlarıdır. Ayrıca makalede, romanın kahramanı Frankeştayn'ın büyük kusurunun bilimsel kibir olduğu tartışılmaktadır.

Anahtar Kelimeler: Edebi Eleştiri, Sosyal Kuram, Rönesans, Faust Figürleri

\section{Introduction}

The idealization of the scientist figure in Frankenstein takes place indirectly and hesitatingly. Shelley`s novel uniquely refashions the social idealization of individuals. This refashioning makes

\footnotetext{
* This study is part of the ongoing doctoral dissertation of the author entitled Moulding and Remoulding the Individual in the Three Myths of Western Civilization: Robinson Crusoe, Frankenstein, and Dracula.

**

Shamil Taha ABDULLAH, Öğr.Gör., Hacettepe Üniversitesi, Modern Diller Birimi, shamil.abdullah@hacettepe.edu.tr, ORCID ID orcid.org / 0000-0003-1796-4239
} 
the idealization of Victor Frankenstein and Walton unnoticed. According to Durkheim (1995), the making of an ideal is part of social life, and an indicator of social transformation. The society needs an ideal to create and recreate itself periodically. During times of radical social change, society "hesitates over the manner in which it must conceive itself. It feels pulled in all directions. When such conflicts break out, they are not between the ideal and the reality but between different ideals, between the ideal of yesterday and that of today" (Durkheim, 1995, p. 425). This historical hesitation gives the novel its uncommon variety of interpretations. The novel puts into opposition the ideal of the past which has the authority of tradition, against the coming into being ideal. On the one hand, the established collective, and religion based, ideal morality stipulates obedience and compliance with the limits of knowledge that divinity allows. It also stipulates sympathy and compassion with other fellow human beings. On the other hand, the new, science based, ideal does not acknowledge any limits on knowledge, and does not observe the old fashioned morality of sympathy. Thus, while Robert Walton wants to satiate his curiosity by seeing the unvisited parts of the world, Victor Frankenstein, with relentless eagerness, pursues "nature to her hiding place" (Shelley, p. 45). The fact that they both suffer (and Frankenstein is severely punished), is a response to the collective ideal of the traditional paradigm. While, at the same time, Walton's glorification of Frankenstein and Frankenstein's encouragement of Walton both represent the idealization of the new paradigm. When sympathizing with the Monster, Frankenstein attends to the traditional ideal of morality; and when rejecting the demand of the Monster, he attends to the

morality of the scientist who considers the long term consequences of his actions, and refuses to keep working on faulty experiment. By destroying the female Monster, Frankenstein, ideally, takes full responsibility, and professionally insists upon terminating his dangerous errored research.

\section{Frankenstein and Science}

Shelley`s novel is about science. In fact, "Frankenstein is our culture`s most penetrating literary analysis of the psychology of modern 'scientific' man, of the dangers inherent in scientific research, and of the exploitation of nature . . . in a technological society" (Mellor, 2007, p. 43). Although it is purely fictional, Frankenstein still conveys valuable realities about the status of science and scientists at the beginning of the nineteenth century. Referring to Frankenstein, Harkup (2018) says that "there is much scientific fact to be found within its pages . . Mary's characters were inventions - although they were heavily based on real people - but the science her characters studied was very real. Even the alchemists that fascinated the fictional Victor Frankenstein were real people" (p. 9). When the Monster contemplates about his own existence (Shelley, 2005, p. 126) he asks himself a variety of questions concerning his identity, his origin, and his destination. Commenting on these questions, Hunter (2008) says:

at the beginning of the nineteenth century these questions resonated with a reading public that was being faced with similarly discomforting scientific revelations. The natural philosophers of the previous century had produced a succession 
of discoveries that argued for a conception of natural and social progress governed not by divine intercession, but by the drive of physical laws (p. 133)

As far as the manifested attitude towards science is concerned, Shelley presents a pessimistic vision about the prospects of scientific research. According to Hutton (2011), "Mary Shelley`s Frankenstein gives vivid expression to what many regard as the evils of modern science - dehumanizing, destructive, mechanistic, malevolent - a monstrous, masculine birth of the male mind. This dystopian image of science struck a chord with her contemporaries and has dominated the scientific imaginary ever since" (p. 17). With such negative image, Shelley embraces the Renaissance attitude which demonstrates non-receptiveness to the imagined potentials of contemporary scientific ventures.

Frankenstein depicts the ramifications of the breakdown of natural philosophy into different branches. According to Hunter (2008), even "Before the sharp division of natural philosophy into its component disciplines, the efforts of the eighteenth-century scientists to classify and understand nature had led a vigorous discourse that conflated ideas of social, economic, political and biological importance" (p. 133). Thus, the novel conveys the tensions, anxieties and apprehensions which accompany such radical transformations in the status and influence of science. In addition to being a projection of the cultural tensions and fears, the Monster of Victor Frankenstein is the forerunner of the future developments in technology. The Monster "is the first of a new species a robot, or more specifically, an android, programmed to destroy all whom its creator outwardly loves" (Tropp, 2007, p. 13). Although he is handmade, he is intelligent and persuasive. Being "Articulate, intelligent, and sensitive, the Monster argues eloquently for its rights to exist [thus] If Victor Frankenstein's frenzied discovery of the 'new alchemy' makes him the first mad scientist, the existence of the Monster presents him with the first and most enduring symbol of modern technology" (Tropp, 2007, p. 13). The Monster, at the same time, is a culmination of the medieval anxious strive of alchemists in search for the legendary philosopher's stone. Thus, Shelley's masterpiece might very well be seen as illuminating the conditions and the paradoxes of science in three eras, the medieval, the early nineteenth century, and the upcoming later times.

Shelley`s novel is also a story about an experiment. McLane (2007) suggests that Frankenstein's experiment goes beyond the prospects of creating an ordinary human being. He exceeds the threshold of knowledge and produces another species. Thus, McLane (2007) says, "Victor`s labors ultimately become not an experiment to create a human being but rather an experiment in speciation, an experiment with extremely heterogeneous materials" (p. 98-99).

\section{The Faustian Paradigm of Science}

This article suggests that Victor Frankenstein is the nineteenth century reincarnation of Faustus. They both have much in common. Referring to the historical Faustus who gained fame in the sixteenth century, Weeks (2013) says that "The career profile of the Wittenberg doctor of theology intimates the hidden pitfalls of academic study or respectability. The acquisition of knowledge of nature is more than a hard bargain on the devil's terms" (p. 21). For both scientists, 
"Nature is ominous and inscrutable because of the diabolical omnipresence within the cosmos" (Weeks, 2013, p. 21). Victor Frankenstein, the nineteenth century scientist, is still affected by the phenomenon of Faustism which "characterizes a society in which human enterprise tends to impose evil terms on whoever undertakes it" (Weeks, 2013, p. 23). Like Frankenstein, the real Faust was merely a proud young academician:

Reliable sources cite the birth of the historical Faustus (first name: Georg, Georgius, or Jörg) in Helmstadt near Heidelberg, in about 1466 . . . This young man began his studies at the University of Heidelberg in 1483. He quickly gained academic degrees as bachelor in 1484 and as a master (magister) of philosophy in 1487. At the age of about twenty-one, the required age for the master's degree, he accomplished what was in his time a major academic achievement. He was proud to call himself magister, philosopher, and doctor (Baron, 2013, p.43).

In spite of his fame, Faustus did not achieve a remarkable advance in any science during his real life. He was condemned because he exerted "effort to exploit a popular new fashion, the renaissance of the occult" (Baron, 2013, p. 49). The German physician, astrologer, and star gazer was demonized for purely historical reasons. According to Baron (2013), diabolical attributes were assigned to Faustus during the last years of his life when the vague reports about Faustus caught the attention of Martin Luther. Faustus was negatively referred to in table conversations by Martin Luther. Baron (2013) says, "Only in those later years, by the time Faustus was over sixty years old, perhaps near the time of his death, did he catch Martin Luther's attention. Comments about him by the reformer totally transformed the Faustus image into a wicked magician" (p. 50). Thus, the location of Faustus in the historical framework of the Reformation led to the demonization of his scientific endeavour and consequently resulted in the birth of the Faustian myth.

However, another historical framework was behind the remarkable spread of the Faustian myth. The story of Faust became very well-known in the 1580 s which witnessed mass witch trials and executions. During the period of witch trials and executions "the authorities managed a mythcreating mechanism that shaped the perception of reality in the general populace" (Baron, 1992, p. 3). At that time, such authorities managed to create fabricated biographies of the victims of those trials. It is within this historical background that the anonymous and mysterious Faust Book, or the Historia von D. Johann Fausten was published in 1587. Because Faustus did not go through such trial during his life time, the anonymous author of the book puts Faustus to a belated trial after his death. In this book, "The narrator succeeds in reconstructing Faustus's life almost beyond recognition of its historical origin" (Baron, 1992, p. 4). The anonymous book represents the opinion of the collectiveness which accuses Faustus of having a pact with the devil and condemns him. Faustus represents the rebellion of the new sciences against the cultural authority of his time. From that time on, Faustus shifted from the realm of history to the realm of myth. The man became a myth which signifies the diabolical nature of science and knowledge. This myth is revived periodically through the later centuries in different forms with a variety of transformations in the 
events and the destiny of the main character. These revivals are reminders for the generations about the damnation of the Faustian archetype who ambitiously seeks boundless freedoms of learning and discovering. The unstated objective of these revivals, including Christopher Marlowe's Faust, in most of the cases is to warn the community against the dangers of knowledge and science.

This article argues that in spite of the substantial divergence between the Faustian myth and Frankenstein, both tales still have essential aspects in common. After all, they both belong to the literature of waring which attempts to guard the individual against exceeding the boundaries of knowledge. In both cases, the protagonists become the scapegoats for the tensions and anxieties of the public towards the newly emerging sciences and disciplines. In addition, the point behind setting a Faustian background for Frankenstein is that Shelley uses the Faustian Renaissance era as a token of the old fashioned and 'exploded' paradigm of science. Shelley does not mention Faustus but she mentions other, Faustus-like and ill-reputed Renaissance scientists such as Cornelius Agrippa, Paracelsus, and Albertus Magnus and describes them as Frankenstein 's "lords" of imagination (Shelley, 2005, p. 32). The acquaintance with Agrippa is behind the birth of Frankenstein's passion for natural philosophy when he was thirteen years of age. It is when he chances to find a volume of the works of Agrippa, and admires the "wonderful facts" that the book relates. It is at this moment that "A new light seemed to dawn upon [his] mind" (Shelley, 2005, p. 29). The Renaissance paradigm is condemned at the very beginning of the novel through the condemnation of Agrippa. When Frankenstein shows Agrippa's book to his father, the father looks at the title page and says, "Ah! Cornelius Agrippa! My dear Victor, do not waste your time upon this; it is sad trash" (Shelley, 2005, p. 29). According to Keefer (2013), Agrippa substantially contributed in the formation of what he calls 'the Faustian Century'. Agrippa`s participation comes from his position within the intellectual domain of the Faustian era, and from his "posthumous demonization, which both paralleled and contributed to the development of the sixteenth-century legend of Faustus" (Keefer, 2013, p. 67). Like Faustus, "Heinrich Cornelius Agrippa (1486-1535) is both historical figure and a myth. To the modern reader, he is first and foremost the archetype of the Renaissance man, the pre-Enlightenment physician, the superstitious astrologer and black magician who tries to overcome the bonds of earthly existence" (Poel, 1997, p. 1). Agrippa published two books and the one which Shelley refers to is most probably the one which deals with the occult philosophy, De occulta philosophia (1531), because Frankenstein chooses a volume and this is the book which consists of three volumes.

In Frankenstein, the Renaissance or the Faustian paradigm of science is set against the newly rising conception of science. Hayden (2011) says that "in the early modern period and following the Restoration of the Stuart monarchy and the establishment of the Royal Society in England, the 'New Science' assumed an exceptional important focus in English literary discourse of the seventeenth and eighteenth centuries" (p. 1). In sharp contrast with the Renaissance paradigm, Shelley`s vision of science is completely non-religious and mundane. In other words, "Mary Shelley embraces the new paradigm of secular science" (Page, 2012, p.100). In fact, Mary Shelley brilliantly 
Shamil Taha ABDULLAH

uses science in creating an integrated myth of both genesis and apocalypse on a purely secular basis.

\section{Specialization and the Enchantment in Science}

Frankenstein negotiates faith in science and the opposition of the public opinions to such faith. Durkheim (1994) emphasizes the authoritative nature of public opinion and the role it plays in shaping negative or positive attitudes towards scientists in societies. Thus, "science is often the antagonist of opinion, the errors of which it combats and corrects [but] science can succeed in this task only if it has sufficient authority, and it can gain such authority only from opinion itself" ( $p$. 210). As such, science is always subsidiary and dependent on social opinion. That is to say, "All the scientific demonstrations in the world would have no influence if a people had no faith in science" (Durkheim, 1994, p. 210). Thus, through the catastrophe of Frankenstein, Shelley articulates the crisis of science itself and its unceasing dependence on social opinion.

It is worth mentioning in this context that Frankenstein discusses the predicament of the individual who chooses science as an occupation at the beginning of the nineteenth century. Victor Frankenstein and Robert Walton are committed professional scientists who choose the search for knowledge as a vocation. In his lecture, "Science as a Vocation", Max Weber discusses the status of science and the commitment to the scientific work in the disenchanted world. Weber's portrayal of the situation of the professional scientists is uniquely compatible with the characterization of Victor Frankenstein and Robert Walton in Shelley`s novel. Weber (2004) draws attention to the fact that science has entered the realm of rigorous specialization when he says, "At the present time, that inner vocation, in contrast to the external organization of science as a profession, is determined in the first instance by the fact that science has entered a stage of specialization that has no precedent and that will continue for all time" (p. 7). In Frankenstein, specialization is dwelled on in more than one way. Walton and Frankenstein are specialized in science in the sense that they have no craft or vocation other than the endeavours they choose to occupy themselves with. It is worth mentioning in this context that the story provides suitable financing for the scientific projects of Frankenstein and Walton. Thus, Frankenstein is a descendant of a well off noble family and Walton is bestowed with the fortune which he suddenly inherits from his cousin.

The other way in which specialization is presented is through the branching of knowledge fields. Though quite Romantically, Walton displays concern about specialization when he shifts his interest between literature (poetry) and science. Before going into the details of his story, Frankenstein describes his journey towards specialization. Frankenstein has an urge to learn, but "not to learn all things indiscriminately" (Shelley, 2005, p. 28). He roughly divides knowledge into two spheres; a sphere that he does not like and a sphere that he likes. The type of knowledge that he does not like consists of different fields. Frankenstein says, "I confess that neither the structure of languages, nor the code of governments, nor the politics of various states possessed attractions for me" (Shelley, p. 28). Frankenstein's "inquiries were directed to the metaphysical, or in the 
highest sense, the physical secrets of the world" (Shelley, p. 28). Still, there is a further field of knowledge that Clerval likes. Clerval becomes occupied with the moral relations. He is interested in the lives of heroes, "and the actions of men" (Shelley, p. 28). After this general delineation of the main fields of knowledge, the novel goes into further specification. The science which Frankenstein has a particular 'predilection' for is natural philosophy. Natural philosophy is the field which determines Frankenstein's fate. After the day he meets $\mathrm{M}$. Waldman, the professor of chemistry at Ingolstadt university, Frankenstein becomes specialized in a particular field within the domain of natural philosophy. From this day, chemistry "became nearly [his] sole occupation" (Shelley, 2005, p. 41). Then he proceeds into further specialization and applies himself "more particularly to those branches of natural philosophy which relate to physiology" (Shelley, 2005, p. 42). Unlike the earlier alchemists, Frankenstein does not distort his attention and effort upon a variety of subjects. Emphasizing the significance of specialization, he says, "A mind of moderate capacity which closely pursues one study must infallibly arrive at great proficiency in that study" (Shelley, 2005, p. 42). Thus, Frankenstein succeeds in arriving at the particular branch of science which serves his purpose the most.

The other characteristic of scientific vocation which Weber draws attention to, and which Frankenstein exceptionally depicts, is passion. Weber (2004) says:

In the absence of this strange intoxication that outsiders greet with a pitying smile, without this passion, this conviction that millennia had to pass before you were born, and millennia more must wait in silence to see if your conjecture will be confirmed - without this you do not possess this vocation for science and should turn your hand to something else. For nothing has any value for a human being as a human being unless he can pursue it with passion. (p. 8)

Victor Frankenstein and Robert Walton have this type of intoxication in science which is viewed with pity by the outsiders. The introductory pages of the novel are mainly reserved for displaying the passion of Walton for knowledge: "I feel my heart glow with an enthusiasm which elevates me to heaven, for nothing contributes so much to tranquilize the mind as a steady purpose - a point on which the soul may fix its intellectual eye" (Shelley, 2005, p. 4). Walton admires and pities Frankenstein because he is familiar with such passion in knowledge. Referring to Frankenstein, Walton says, "He excites at once my admiration and my pity to an astonishing degree" (Shelley, 2005, p. 17). In the same pattern, Frankenstein pities Walton and he describes the passion for science as intoxication when saying, "Unhappy man! Do you share my madness? Have you drunk also of the intoxicating drought?" (Shelley, 2005, p. 17). The pity between the main characters leaves no space for pitying the Monster. Describing the passionate ardour which propelled him while creating the Monster, Frankenstein says, that "he seemed to have lost all soul or sensation but for this one pursuit" (Shelley, 2005, p. 45). Such passion and devotion to a specific purpose are the means towards establishing an individualistic self in the realm of science. Emphasising the role of devotion, Weber (2004) says, "in the realm of science, the only person to have 'personality' is the one who is wholly devoted to his subject" (p. 10). Walton and Frankenstein are passionately 
after establishing scientifically recognizable selves. For Frankenstein, the ultimate aim is supreme enough to justify the creation of a living creature without any considerations to the welfare and emotions of that creature. The same passion justifies risking the lives of the sailors on Walton's ship among the mountains of ice in the frozen ocean.

\section{The Modern Paradigm of Science}

The novel contrives a new type of hubris. Victor Frankenstein is scientifically hubristic individual. The rise of the systematic scientific endeavours leads to the establishment of standard conventions which regulate the scientific work. Unlike art, science is based on progress. Weber (2004) says that "Scientific work is harnessed to the course of progress" (p. 11). Science has specific nature which makes it different from art. A fulfilling work of art for Weber cannot be surpassed. Art does not grow old. In contrast, in the realm of science, Weber adds:

we all know that what we have achieved will be obsolete in ten, twenty, or fifty years. That is the fate, indeed, that is the very meaning of scientific work . . Every scientific fulfilment gives birth to new questions and cries out to be surpassed and rendered obsolete. Everyone who wishes to serve science has to resign himself to this. (Weber, 2004, p. 11)

This means that "to be superseded scientifically is not simply our fate but our goal. We cannot work without living in hope that others will advance beyond us" (Weber, 2004, p. 11). Shelley's novel displays awareness of the concept of progress in science. Walton is cognizant of this peculiarity of science. Although Romantically far-fetched and exaggeratedly ambitious, Walton's aim, is scientifically dexterous. Walton wants to contribute, if his endeavour would be successful, to the movement of science through providing the useful scientific keys, such as the secret of the magnet, that other generations of scientists and researchers would need in the future. Walton says, "you cannot contest the inestimable benefit which I shall confer on all mankind, to the last generation, by discovering a passage near the pole to those countries, to reach which at present so many months are requisite; or by ascertaining the secret of the magnet, which if at all possible, can only be affected by an undertaking such as mine" (Shelley, p. 4). Thus, despite his illusions, Walton observes the scientific standards of his age. His aims, if achieved, would add significant layers to the accumulation of human knowledge. He does not attempt to finalize the quest for knowledge in the scientific field which he serves. Thus, in spite of his delusions, Walton does not have scientific hubris which leads to his destruction.

On the other hand, Frankenstein's hamartia lies in his non-compliance with this eccentricity of modern science. Frankenstein is a disciple of the old paradigm alchemists whose systems and principles are out of fashion. Addressing Frankenstein, professor Krempe says, "I little expected, in this enlightened and scientific age, to find a disciple of Albertus Magnus and Paracelsus" (Shelley, 2005 , p. 36). However, Frankenstein realizes that the systems of those old authors "had been entirely exploded and that a modern system of science had been introduced which possessed 
much greater powers than the ancient" (Shelley, 2005, p. 30). What he fails to recognize is that the approach of those authors was erroneous and invalid. Frankenstein abandons those authors but he imitates their methods. Like the forgotten alchemists, he overlooks the accumulative nature of science. What he has in common with the ancient scientists is that he is imbued "with a fervent longing to penetrate the secrets of nature" (Shelley, p. 30). He is not satisfied with the discoveries of modern philosophers particularly because their approach is gradual and cumulative. He thinks that the modern philosophers fail in achieving useful results and breakthroughs. The infinity of knowledge makes Frankenstein anxious. Referring to the infinitude of science, Frankenstein says, "Sir Isaac Newton is said to have avowed that he felt like a child picking up shells beside the great and unexplored ocean of truth" (Shelley, 2005, p. 30). Professor Waldman provides guidance for Frankenstein and emphasises the progressive nature of modern chemistry when he says, "The ancient teachers of this science promised impossibilities and performed nothing. The modern masters promise very little; they know that metals cannot be transmuted and that the elixir of life is a chimera" (Shelley, 2005, p. 38). M. Waldman, wisely, appreciates the role of the ancient chemists as contributors to the movement of science, but he warns Frankenstein that those scientists were "erroneously directed" (Shelley, p. 39). In spite of all these warnings and advices, the dissatisfied Frankenstein ventures enthusiastically "into the search of the philosopher's stone and the elixir of life" (Shelley, 2005, p. 31). He ignores the progressive nature of modern scientific research and attempts to achieve immoderate and uttermost ends. He imagines the glory which would accompany the banishing of disease which might afflict the human body. In his wild thinking, Frankenstein reflects, "more, far more, will I achieve; treading in the steps already marked, I will pioneer a new way, explore unknown powers, and unfold to the world the deepest mysteries of creation" (Shelley, p. 31-32). In spite of his erroneous approach, Frankenstein arrives at one point to the summit of his desires and succeeds in finding the secret of life. After long days and nights of restless labour and weariness, he "succeeded in discovering the cause of generation and life" (Shelley, p. 43), and becomes capable of bestowing life upon lifeless matter. But, instead of the standard procedure of declaring, and sharing the new discoveries with other researchers and colleagues, Frankenstein, proceeds with his faulty procedure and decides to create a creature when he finds "so astonishing a power placed within [his] hands" (Shelley, 2005, p. 44).

Frankenstein does not want to submit his discovery to other scientists to improve it and put it into proper use. Unlike the scientists of his time, he does not want to be surpassed and superseded. He does not put his transcendental aim of serving humanity into the proper channels of science. What he does not realize is that "The scientific attitude is experimental as well as intrinsically communicative" (Dewey, 1999. P. 172). Dewey (1999) asserts that "No scientific inquirer can keep what he finds to himself or turn it to merely private account without losing his scientific standing. Everything discovered belongs to the community of workers. Every new idea and theory has to be submitted to this community for confirmation and test" (p. 170). Frankenstein's ego diverts him from the standard procedures of the contemporary scientific conduct. 
In order to make his findings concrete and tangible, Frankenstein chooses to build a frame. His egotism pushes him towards the utmost limits. Blinded by his first success, he decides to create a complete human being; and this particular decision eventually leads to his own destruction. Such perspective gives further dimension to the poetic justice in Frankenstein. It is particularly the scientific hubris which brings about the destruction of the hero. Frankenstein is particularly afflicted by this type of conceit. At the personal level, he is noble, moderate, and humble. But, according to Bloom (2007), Frankenstein is the pragmatic and "the true monster of the novel" (p. 9). In addition to his unjustified prejudice against his creature, Frankenstein's monstrosity lies in his scientific pride and arrogance which can be attributed to his stereotypical approach to science, Frankenstein mercilessly views the sensible Monster as a mere outcome of a botched experiment. And in this way he brings about his own downfall.

\section{The Rebel Scientist}

From an opposite perspective, Frankenstein can be seen as an individual who rebels against the current status of science in his time. A careful consideration of the status of science in general, and its position in the beginning of the nineteenth century, would reveal that the dissatisfaction of Frankenstein is not without logical basis. According to Weber (2004), there is a problem in the meaning of science because the principle of progress is infinite. The fact that scientists should endlessly aim at being superseded and surpassed means that the scientific endeavour is irritatingly endless. Therefore, Weber wonders:

What is the point of engaging in something that neither comes, nor can come, to an end in reality? ... What meaningful achievement can he [the scientist] hope for from activities that are always doomed to obsolescence? What can justify his readiness to harness himself to this specialized, never-ending enterprise? That question calls for some general reflection (Weber, 2004, pp. 11-12)

These are the concerns, in fact, that Frankenstein originally reacts against. What is the point of engaging in something that is never finalized and that is always doomed to obsolescence? This is why Frankenstein always comes discontented and dissatisfied after studying the discoveries of modern philosophers. The same reason makes Sir Isaac Newton like an ignorant child beside the great and unexplored ocean of knowledge. For Frankenstein, the successors of Isaac Newton in all the branches of natural philosophy which he has acquaintance with, "appeared even to [his] boy's apprehensions as tyros engaged in the same pursuit" (Shelley, 2005, p. 30). Frankenstein even resentfully compares the scientists of his time with uneducated peasants who are merely acquainted with the practical uses of the elements around them. For Frankenstein:

The most learned philosopher knew little more. He had partially unveiled the face of Nature, but her immortal lineaments were still a wonder and a mystery. He might dissect, anatomize, and give names; but, not to speak of a final cause, causes 
in their secondary and tertiary grades were utterly unknown to him (Shelley, 2005, p. 30)

Moreover, Frankenstein discredits the education system of his time. Thus while he "followed the routine of education in the school of Geneva, [he] was, to a great degree, self-taught with regard to [his] favourite studies" (Shelley, 2005, p. 31). He harshly criticizes the monotonously progressive nature of science which Weber refers to. Old scientists for Frankenstein are more knowledgeable because they "had penetrated deeper"; and that is why, he takes "their word for all that they averred and [he] became their disciple" (Shelley, 2005, pp. 30-31). Unlike old scientists, modern ones don't have recognizable and really profitable finalized aims. They seem like being trapped in a dark cave with no light to indicate the exit which leads out of this darkness. This metaphor is used by Frankenstein when he achieves his desired breakthrough and becomes able to bestow animation upon lifeless matter. Frankenstein compares himself to "the Arabian who had been buried with the dead and found a passage to life, aided only by one glimmering and seemingly ineffectual light" (Shelley, pp. 43-44). In order to go out of the infinite circle of obsolescence and achieve the desired scientific finalization, Frankenstein uses the right means, but with faulty procedure. He uses the means and the resources of modern science, but he maintains the attitude of ancient chemists. He succeeds in the theoretical part. His catastrophic mistake lies in the practical part. He needs the creature in order to test the applicability of his theories and to consummate his venture. He needs to eternally register his theoretical achievement in his creature. The creature would be a live testimony and authentication of Frankenstein's discovery of the secret of life.

It is worth noting here that Frankenstein is competent in natural philosophy and chemistry; and through research in these fields he discovers the secret of life. The assembling of the creature is another task which needs different expertise. The negative effect of the out-dated attitude of the old paradigm chemists becomes evident particularly in the second stage of Frankenstein's venture, in which he decides to build the human frame. In his rush towards finalization, he sacrifices perfection. He knows that his work would be imperfect. He prepares himself for a variety of reverses. He knows that his "operations might be incessantly baffled, and at last [his] work be imperfect" (Shelley, p. 44). Yet when he considers the improvements which take place in mechanics every day, he becomes encouraged to hope that his current attempt would be perfected in the future by other specialist technicians. This means that Frankenstein's intention is to make a prototype that can be used as a template, and can, at the same time, be improved by other, more specialist scientists and technicians. Therefore, in order to overcome the minute technical issues of structuring the frame, he chooses to make his human huge in size. He says, "As the minuteness of the parts formed a great hindrance to my speed, I resolved, contrary to my first intention, to make the being of a gigantic stature" (Shelley, 2005, p. 44). As a result, the piece of art which Frankenstein intends to create, turns out to be monstrous in shape and hideous. Thus, while he succeeded in the purely scientific part of his project, he fails in the part which requires technical skills. 
Therefore, the consideration of the conditions of science in the novel reveals that Frankenstein articulates the tension between science and society at the threshold of modernity. The titular character represents an exemplification of the irresolute scientist who lives in a transitional period in the history of science. In fact, Walton and Frankenstein are both old paradigm explorers who try to establish their individuality at this critical period. While Frankenstein and Walton fail in complying with the new rules of scientific conduct, the public opinion at the same time fails in adjusting with the idea that science can provide answers for all the questions. The punishment of Frankenstein and the failure of Walton are attributed to the fact that science as a path to nature is still considered as blasphemy to the ears of people at the beginning of the nineteenth century. It is worth mentioning in this context that Frankenstein is severely punished not only because he is a resurrectionist, but also because he practices anatomy and surgery. McNally, affirms that, anatomists and surgeons were despised by ordinary English people at the end of the eighteenth century. Referring to Frankenstein, McNally (2011) says:

the resonance of this story owed much to actual phenomena, which became points of contestation at the gallows in eighteenth-century London, as the urban crowd fought to save the bodies of the hanged from anatomists seeking to procure corpses for dissection [therefore] for the British working class, anatomists, surgeons and resurrectionists were all part of a general conspiracy to degrade and oppress the poor in both life and death through kidnapping, murdering, grave-robbing and dissection (p. 12).

Thus, though such practices are done for the sake of science and progress in medicine, the society still views them as transgressions against the collective norms, and signs of individual nonconformity and dissonance that require harsh punitive measures.

\section{Conclusion}

Shelley's novel depicts the ramifications of being enchanted with science. It signifies the historical reluctance of the society in moulding the ideal individual during the times of radical social changes. Walton and Frankenstein are the ideals of the present who are rebuked and punished by the ideal of the past. They are ideals of the present because they both endorse the idea that modern science should not adhere to certain limits. They are ideals of the present because they are more specialized and devoted. They do not observe the traditional morality of sympathy and compassion when it hinders the ultimate objective of their vocation. By sympathizing with the Monster, Frankenstein departs from the technical attitude and attends to the traditional morality. When professionally calculating the probable consequences of creating a female monster, Frankenstein adheres again to the scientific ideal and bravely shoulders the complete responsibility of his errored research. The idealization of the newly emerging scientific spirit is only manifested through Walton's glorification of Frankenstein and though Frankenstein's encouragement of Walton. Otherwise, the novel takes the side of the traditional ideal; Walton fails, and Frankenstein 
is mercilessly tortured and then put to death. As a humble and noble man, Frankenstein does not deserve such fate. The punitive effect is ensued by his scientific hubris. He, on purpose, disregards the maxims of modern scientific research which stipulate that scientific fulfilments should be presented for others in order to be improved. Methodologically, Victor Frankenstein follows the path of the medieval alchemists who attempt to reach ultimate and fixed ends that others cannot supersede. Walton and Frankenstein are the scientists of the transitional era who stand astride on two different worldviews. While Walton transforms, the metamorphosis of Frankenstein comes late.

\section{References}

Anonym. (1587). Historia von D. Johann Fausten. Vollständige Neuausgabe Herausgegeben von Karl-Maria Guth. Berlin, Germany: Contumax Gmbll \& Co. KG.

Baron, F. (1992). Faustus on Trial: The Origin of Johann Spies's 'Historia' in an Age of Witch Hunting. Tübingen, Germany: Max Niemeyer Verlag GmbH \&Co. KG.

Baron, F. (2013). Faustus of the Sixteenth Century: His Life, Legend, and Myth. In J. M. van der Laan and A. Weeks (Eds.), The Faustian Century: German Literature and Culture in the Age of Luther and Faustus. (pp. 43-66). New York: Camden House.

Bloom, H. (2007). Bloom`s guides: Mary Shelley`s Frankenstein. New York: Info base Publishing.

Dewey, J. (1999). Individualism Old and New. New York: Prometheus Books.

Durkheim, E. (1995). The Elementary Forms of Religious Life. New York: The Free Press.

Harkup, K. (2018). Making the Monster, the Science Behind Mary Shelley`s Frankenstein. London, UK: Bloomsburg Publishing.

Hayden, J. A. (2011). Women, Education, and the Margins of Science. In J. A. Hayden (Ed.). The New Science and Women`s Literary Discourse: Prefiguring Frankenstein (pp. 1-16). New York: Palgrave McMillan.

Hunter, A. (2008). Evolution, Revolution, and Frankenstein`s Creature. In C. K. Wolf \& J. Goodall. Frankenstein`s Science: Experimentation and Discovery in Romantic Culture 1780-1830 (pp. 133-150). Hants, UK: Ashgate Publishing Limited.

Hutton, S. (2011). Before Frankenstein. In J. A. Hayden (Ed). The New Science and Women's Literary Discourse: Prefiguring Frankenstein (pp.17-28). New York: Palgrave McMillan.

Keefer, M. (2013). Cornelius Agrippa`s Double Presence in the Faustian Century. In J. M. van der Laan \& A. Weeks (Eds.). The Faustian Century: German Literature and Culture in the Age of Luther and Faustus (pp. 67-92). New York: Camden House. 
McLane, M. N. (2007). Population, Humanity, and Frankenstein. In H. Bloom (Ed.). Bloom's Modern Critical Interpretations: Mary Shelley`s Frankenstein (pp. 95-124). New York: Chelsea House, an imprint of Infobase Publishing.

McNally, D. (2011). Monsters of the Market: Zombies, Vampires, and Global Capitalism. Leiden, The Netherland: Koninklijke Brill.

Mellor, A. (2007). Making a Monster. In H. Bloom (Ed.). Bloom`s Modern Critical Interpretations: Mary Shelley`s Frankenstein (pp. 43-60). New York: Chelsea House, an imprint of Infobase Publishing.

Page, M. R. (2012). The Literary Imagination from Erasmus Darwin to H. G. Wells: Science, Evolution, and Ecology. New York: Routledge, Taylor \& Francis Group.

Poel, M. (1997). Cornelius Agrippa: The Humanist Theological and his Declamations. Leiden, The Netherlands: Brill.

Shelley, M. (2005). Frankenstein. San Diego: ICON Group International, Inc.

Tropp, M. (2007). The Monster. In H. Bloom (Ed.). Bloom`s Modern Critical Interpretations: Mary Shelley`s Frankenstein (pp. 13-28). New York: Chelsea House, an imprint of Infobase Publishing.

Weber, M. (2004). The Vocation Lectures. Indianapolis: Hackett Publishing Company.

Weeks, A. (2013). The German Faustian Century. In J. M. van der Laan \& A. Weeks (Eds.). The Faustian Century: German Literature and Culture in the Age of Luther and Faustus (pp. 17-42). New York: Camden House. 